\title{
Modeling The Relationships Between Export, Import, Inflation, Interest Rate, and Rupiah Exchange
}

\author{
Nina Valentika*, Vivi Iswanti Nursyirwan, Ilmadi \\ Pamulang University, Indonesia
}

\section{ARTICLE INFO \\ Article History \\ Received : 30-07-2020 \\ Revised :08-09-2020 \\ Accepted : 15-09-2020 \\ Published : 30-09-2020 \\ Keywords: \\ Causality;macroeconomic variable;regression; vector autoregressive. \\ *Correspondence: E-mail: dosen02339@unpam.ac.id \\ Doi: \\ $\underline{10.24042 / \operatorname{djm} . v 3 i 3.6942}$}

\begin{abstract}
This research was a modification of research by Catalbas (2016) and Pratikto (2012). The model that can separate long-term and shortterm components are the Vector Error Correction Model (VECM). This study aimed to model export, import, inflation, interest rates, and the rupiah exchange rate using VECM and to test the causality between variables using the Granger Causality test. The inter-variable model obtained in this study was VECM with lag 2 using a deterministic trend with the assumption of none intercept no trend and two cointegrations. In export and import, there was an adjustment mechanism from the short-term to the long-term. This research model was appropriate to forecast the export and import where VECM with export and import as the target variables, the cointegration equation (long-run model) for $\boldsymbol{e c t}_{\boldsymbol{t - 1}}$, and the cointegration equation (long-run model) for $\boldsymbol{e c t}_{\boldsymbol{t}-\mathbf{2}}$. Based on the Granger Causality test, it was found that there was a one-way relationship between exchange rates and inflation, export and interest rates, export and import, inflation and export, and import and the interest rate at the significance level of $5 \%$.
\end{abstract}

http://ejournal.radenintan.ac.id/index.php/desimal/index

\section{INTRODUCTION}

The world economic development requires every country to expand its market network through international trade. Economic growth in the era of globalization can be seen from the increased interaction between countries around the world. The intensity of the interaction is marked by the increasing relationship between countries to complement the needs of one country to another. To conduct a transaction in international trade, an agreed-upon currency is needed to be used in the transactions, in this case, the US dollar (United States). The use of the US dollar causes the exchange rate of the rupiah to fluctuate from time to time. There is a risk of changes in the currency exchange rates caused by the uncertainty of the exchange rate itself (Muzakky et al., 2015).

As reported by Bisnis.tempo.co, the Governor of Bank of Indonesia, Perry 
Warjiyo, state that the reduced inflow of foreign capital into the domestic financial market after the spread of COVID-19 has depressed the rupiah exchange rate. The lack of foreign capital inflows has pressured and weakened the rupiah exchange rate since mid-February 2020. "As of March 18, the rupiah, compared to the end of 2019, had depreciated by around 8.77 percent. This is in line with the weakening of other developing country currencies" (Muhammad Hendartyo, 2020).

International trade Transactions utilize different types of currency which make the exchange rate a measuring tool in transactions. Mankiw (2008) states that the exchange rate is the price level agreed upon by countries to trade. However, the weakening of the exchange rates can cause difficulties for the business world, especially for those who bring in raw materials from abroad and can disrupt the stability of domestic prices of goods. For this reason, the role of the state needs to be done in safeguarding economic fundamentals and in maintaining the stability of a country's macroeconomic (Mankiw, 2008).

According to Chou (2000), the fluctuation of the exchange rate shows the amount of volatility where the greater the volatility, the greater the exchange rate movements, namely the appreciation and depreciation. This condition is influenced by economic factors, both domestic and foreign. These factors can be fundamental, technical, and market sentiment factors (Chou, 2000).

The free economic impacts on the balance of payments of a country which concerns trade flows and capital flows. Trade flows can be influenced by exchange rate policies to maintain export competitiveness and suppress imports to reduce the current account deficit. The effect of exchange rate policies on the economy can be seen from two sides, namely demand and supply (Mankiw, 2008).

On the other hand, inflation has a major influence on exchange rate fluctuations. If the inflation rate in Indonesia increases significantly while the inflation rate in the United States is relatively constant, it will make product prices in Indonesia even more expensive. This price increase will affect demand for the rupiah currency because consumers will divert product purchases to the United States which have relatively cheap prices (Madesha et al., 2013). Also, high inflation will weaken the purchasing power, especially for domestic products, which in turn can reduce the value of public confidence in the domestic exchange rates.

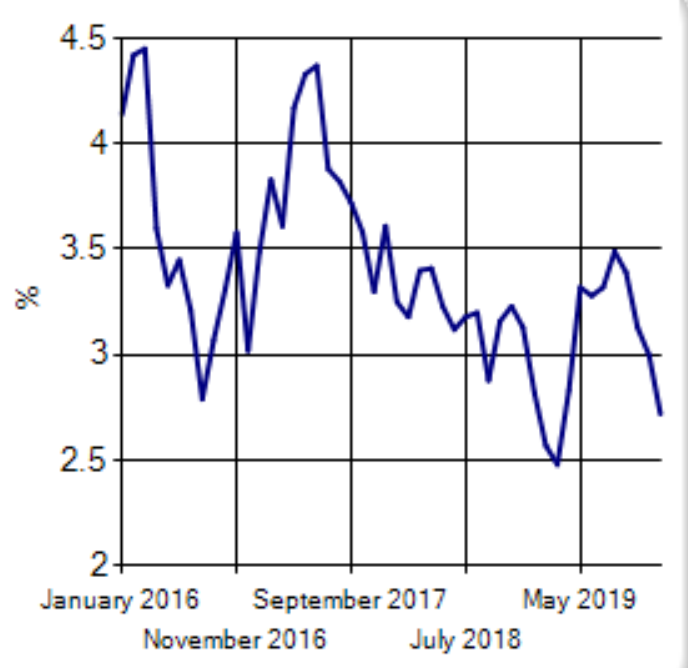

Figure 1. The Inflation Rate in Indonesia in 2016-2019

Source: (Bank Indonesia, 2020)

Inflation can trigger import growth to develop faster than export growth (Sukirno, 2002), It can be said that inflation has a negative relationship with export. This tendency is due to the effects of inflation, namely (1) inflation causes the prices of domestic goods to be more expensive than the prices of foreign goods. Therefore, inflation tends to increase import and causes the demand for foreign exchange to increase. (2) Inflation causes 
the price of exported goods to be expensive so that inflation tends to reduce export which causes the supply of foreign currency to decrease. Thus, the price of foreign currency will increase (Sukirno, 2013).

Another macroeconomic indicator that is thought to affect the rupiah exchange rates is the SBI interest rate. Exchange rate fluctuations, which changes the inflation rates, can eventually lead to increases and decreases in domestic interest rates. Bank Indonesia, which has the policy to control the interest rates, is expected to create stability in the value of the rupiah. This is because changes in interest rates influence the flow of funds in a country so that it can affect the demand or supply of currency exchange rates.

According to Mishkin (2008), changes in domestic interest rates are often a common factor affecting the exchange rates. When the domestic real interest rate increases, the domestic currency appreciates. Conversely, when the domestic interest rate increases towards the expected inflation development, the domestic currency will depreciate (Mishkin, 2008). Kewal (2012) examines the inflation, interest rates, exchange rates, GDP growth, and the composite stock price index (IHSG) (Kewal, 2012). According to Rinaldi (2019), GDP and growth rates can measure welfare in the development of the economic sector (Rinaldi, 2019). Kewal (2012) discovers that JCI is influenced by exchange rates (Kewal, 2012).

Other research on macroeconomic variables had been done by Pratikto (2012) and Catalbas (2016). The dynamics between the real effective exchange rate and macroeconomics variables in Indonesia were studied by Pratikto (2012). Pratikto (2012) shows that the movement of export, import, and inflation is related to the real effective exchange rate (Pratikto, 2012).
The relationship between nominal exchange rates, import, and export in Turkey for the period of 1998: 1 to 2015: 3 was examined by Catalbas (2016) using the Vector Autoregressive (VAR) model on three months worth of data. Catalbas (2016) shows that the exchange rate does not affect export, import, and trade balance while the import restriction measures have a negative impact on export (Catalbas, 2016).

The current standard VAR system generally comes from the primitive VAR system which has several weaknesses. The restricted form of VAR is the Vector Error Correction Model (VECM) (Enders, 2014). Additional restrictions are given so that the data is not stationary at a certain level but can be co-integrated (Firdaus, 2011). According to Verbeek (2008), cointegration describes a long-term relationship (Verbeek, 2008). The VECM model has two main estimator outputs, namely measuring cointegration and error-correction (Besimi et al., 2006). The long-term and short-term components are separated by the VECM procedure (Lütkepohl, 2005).

Research by Silitonga RBR et. al (2017) employs multiple linear regression analysis to analyze the export, import, and inflation on the rupiah exchange rates in Indonesia. Thus, it is necessary to research the export, import, inflation, interest rates, and rupiah exchange rates through VECM (Silitonga et al., 2017).

Based on the background of the problem and some of the literature that has been described, this study aimed to model the export, import, inflation, interest rates, and the rupiah exchange rates using VECM and to test the causality between variables using the Granger Causality test. The results of this study are expected to be used as consideration for policymakers in controlling the rupiah exchange rates. 
Desimal, 3 (3), 2020 - 250

Nina Valentika*, Vivi Iswanti Nursyirwan, Ilmadi

\section{METHOD}

This research was a secondary data analysis through the quantitative approach. The monthly data period used was January 2009 to December 2019. There were five variables of this study, namely total export value, total import value, inflation rates, interest rates, and rupiah exchange rates. The types and sources of data of this research were the secondary data, namely, data sourced from the official website publication of the Bank of Indonesia (BI) and the Central Statistics Agency (BPS).

The statistical testing was assisted by the EViews software with the following research steps:

1. Exploring monthly data by looking at the movement of the export, import, inflation rates, interest rates, and rupiah exchange rates during a predetermined period.

2. Checking the stationarity of the data in the mean of each variable through the Augmented Dickey-Fuller (ADF) test.
3. Determining the optimum lag through the Smallest Schwarz Information Criterion (SC) value.

4. Performing Granger's causality test on the export, import, inflation rates, interest rates, and the rupiah exchange rate variables.

5. If the data is stationary, the model used is VAR with p-order. If the data is not stationary, the Johansen's cointegration test is used. If the cointegration rank $(r)=0$, then the porder VAR model with distinction is used. But if $r>0$, then the model used is the VECM p-order rank $r$.

6. Estimating the parameters of VAR (p), VARD (p), or VECM model using EViews.

7. Diagnostic testing of the model is done to ensure that the model obtained meets the assumptions and is suitable for use.

8. Forecasting five months' worth of data using the model.

9. Evaluating the forecast by considering the relative error generated by using a tolerance limit of $5 \%$. 
Desimal, 3 (3), 2020 - 251

Nina Valentika*, Vivi Iswanti Nursyirwan, Ilmadi

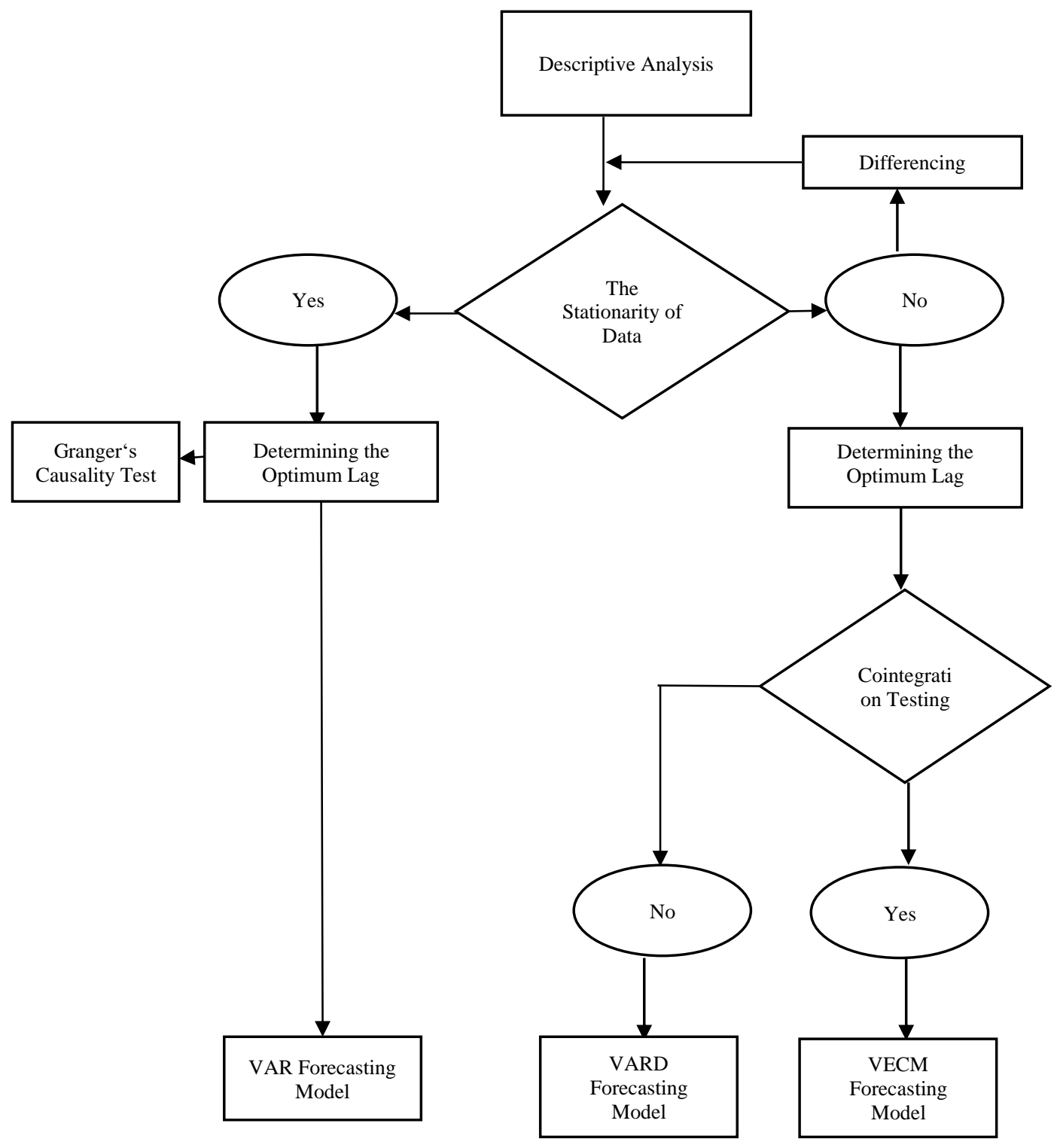

Figure 2. Research Flow

\section{RESULTS AND DISCUSSION}

One of the problems with the time series data is the non-stationary data. Special actions need to be applied in time series analysis due to the potential for false regression results (Granger et al., 1974). The ADF test is used to check whether the data is stationary or not. The results of the stationary data test at a significance level of $5 \%$ can be seen in Table 1.

Table 1. The Results of the Stationary Data Test

\begin{tabular}{llll}
\hline \multicolumn{1}{c}{ Variable } & t-Statistic & $\begin{array}{r}\text { MacKinnon's 5\% } \\
\text { Significance level }\end{array}$ & \multicolumn{1}{c}{ Results } \\
Import & -2.507625 & -3.448021 & Not Stationary \\
Export & -3.948239 & -3.444756 & Stationary \\
Exchange Rates & -4.196178 & -3.444756 & Stationary \\
Inflation Rates & -2.853632 & -3.445030 & Not Stationary \\
Interest Rates & -2.189573 & -3.445030 & Not Stationary \\
\hline
\end{tabular}


Based on Table 1, it was found that the export variables and the exchange rates were stationary at the $5 \%$ level. The result of the first difference of the stationary data at a 5\% significance level can be seen in Table 2 .

Table 2. The First Difference Test Results

\begin{tabular}{llll}
\multicolumn{1}{c}{ Variabel } & \multicolumn{1}{c}{ t-Statistic } & $\begin{array}{c}\text { MacKinnon's 5\% } \\
\text { Significance level }\end{array}$ & \multicolumn{1}{c}{ Results } \\
Import & -2.443620 & -3.448021 & Not Stationary \\
Export & -11.86077 & -3.445030 & Stationary \\
Exchange Rates & -8.789074 & -3.444756 & Stationary \\
Inflation Rates & -7.901848 & -3.445030 & Stationary \\
Interest Rates & -7.061221 & -3.444756 & Stationary \\
\hline
\end{tabular}

Based on Table 2, the export variables, exchange rates, inflation rates, and interest rates were stationary. The results of the stationary data test on the second difference at the $5 \%$ significance level can be seen in Table 3 .

Table 3. The Second Difference Test Results

\begin{tabular}{|c|c|c|c|}
\hline Variable & t-Statistic & $\begin{array}{c}\text { MacKinnon } \\
\text { critical point } \\
5 \% \text { level }\end{array}$ & Results \\
\hline Import & -6.864874 & -3.448681 & Stationary \\
\hline Export & -7.114187 & -3.448021 & Stationary \\
\hline Exchange Rate & -14.27714 & -3.445308 & Stationary \\
\hline Inflation & -8.844436 & -3.446168 & Stationary \\
\hline Interest Rate & -17.44473 & -3.445030 & Stationary \\
\hline
\end{tabular}

Based on Table 3, it can be seen that all variables were stationary.

The optimum lag had been obtained from the stationary VAR system. The optimum lag was obtained by testing the stability of the VAR. The optimum lag obtained for the VAR model is considered stable at 14 . The lag with the smallest Schwarz Information Criterion (SC) value was the optimum lag used in this study. The results of selecting the optimum lag can be seen in Table 4 .

Table 4. Selection of the Optimum Lag

\begin{tabular}{cc}
\hline Lag & SC \\
0 & 4. Table-23.34443 \\
1 & -24.15621 \\
2 & $-24.42057 *$ \\
3 & -24.10667 \\
4 & -23.67256 \\
5 & -23.12480 \\
6 & -22.48091 \\
7 & -21.75298 \\
8 & -21.21633 \\
9 & -20.83946 \\
10 & -20.10519 \\
11 & -20.27566 \\
12 & -19.58902 \\
13 & -19.25115 \\
14 & -18.72538 \\
\hline
\end{tabular}

*shows the lag sequence selected based on criteria 
Based on Table 4, lag 2 had the smallest SC value. Thus, the optimal lag used in this study was 2 .

Before performing the cointegration testing, it was necessary to determine the deterministic trend assumption. The results of selecting the deterministic trend assumptions for the model can be seen in Table 5 .

Table 5. The Results of Selecting Deterministic Trend Assumptions

\begin{tabular}{cccccc}
\hline $\begin{array}{c}\text { Data Trend: } \\
\text { Rank or }\end{array}$ & $\begin{array}{c}\text { None } \\
\text { No Intercept } \\
\text { No Trend }\end{array}$ & $\begin{array}{c}\text { None } \\
\text { Intercept } \\
\text { No Trend }\end{array}$ & $\begin{array}{c}\text { Linear } \\
\text { Intercept } \\
\text { No Trend }\end{array}$ & $\begin{array}{c}\text { Linear } \\
\text { Intercept } \\
\text { Trend }\end{array}$ & $\begin{array}{c}\text { Quadratic } \\
\text { Intercept } \\
\text { Trend }\end{array}$ \\
0 & $-26.31684^{*}$ & $-26.31684^{*}$ & -26.18034 & -26.18034 & -26.03137 \\
1 & -26.14778 & -26.14043 & -26.04038 & -26.03442 & -25.89964 \\
2 & -25.94689 & -25.92910 & -25.85569 & -25.82301 & -25.72336 \\
3 & -25.66465 & -25.64162 & -25.59900 & -25.54982 & -25.48120 \\
4 & -25.32319 & -25.32165 & -25.31458 & -25.23827 & -25.20371 \\
5 & -24.94648 & -24.93832 & -24.93832 & -24.91323 & -24.91323 \\
\hline
\end{tabular}

Based on Table 5, the SC assumption suggested that the model should use the deterministic assumption with no intercept and no trend as well as none intercept no trend. The none intercept and no trend were chosen as the deterministic trend assumption because they had the largest adjusted R-Squared value.

Cointegration testing was done using the Johansen's cointegration test based on the Trace test. The results of Johansen's cointegration test can be seen in Table 6 .

Table 6. The results of the Johansen's Cointegration Test

\begin{tabular}{ccccc}
\hline $\begin{array}{c}\text { Hypothesized } \\
\text { No. of CE (s) }\end{array}$ & $\begin{array}{c}\text { Eigenvalue } \\
\text { None }{ }^{*}\end{array}$ & $\begin{array}{c}\text { Trace } \\
\text { Statistic }\end{array}$ & $\begin{array}{c}\mathbf{0 : 0 5} \\
\text { Critical Value }\end{array}$ & Prob. ** \\
& $\begin{array}{l}\text { 89.45980 } \\
\text { 76.97277 }\end{array}$ & & & \\
At most 1 & 0.0041 & & & 0.211790 \\
At most2 & 0.183781 & 58.75903 & 54.07904 & 0.0180 \\
At most 3 & 0.119195 & 32.56272 & 35.19275 & 0.0936 \\
At most 4 & 0.090119 & 16.19023 & 20.26184 & 0.1657 \\
Trace test indicates 2 cointegrating eqn (s) at the 0.05 level & & \\
* denotes rejection of the hypothesis at the 0.05 level & & \\
** MacKinnon-Haug-Michelis (1999) p-values &
\end{tabular}

Based on table 6, it was found that the trace test showed 2 significant cointegrations ata $5 \%$ significance level.The next step was to estimate the VECM model parameters.

The inter-variable model in this study was VECM with lag 2 using a deterministic trend with the assumption that there was no intercept and no trend and there were 2 cointegrations. Based on the Breusch-Pagan-Godfrey, it was found that the variance of the residuals was constant at the 5\% significance level. Based on the Breusch-Pagan-Godfrey Serial Correlation LM Test, it was found that there was no autocorrelation problem at the 5\% significance level.

The VECM model between macroeconomic variables has 5 models where each variable is the target variable.

VECM with export as the target variable is as follows 


$$
\begin{aligned}
\Delta \text { export }_{t}=- & 0.058378 \text { ect }_{t-1}-0.136997 \text { ect }_{t-2}-0.770885 \Delta \text { export }_{t-1} \\
& -0.064200 \Delta \text { export }_{t-2}+0.101808 \Delta \text { import }_{t-1}-0.118906 \text { import }_{t-2} \\
& -0.717528 \Delta \text { inflation }_{t-1}-2.461659 \text { inflation }_{t-2} \\
& +0.490593 \Delta \text { exchangerate }_{t-1}-0.402662 \Delta \text { exchangerate }_{t-2} \\
& -1.287147 \Delta \text { interestrate }_{t-1}+1.612054 \text { interestrate }_{t-2}
\end{aligned}
$$

Table 7 indicates that the VECM estimate of export which showed a shortterm variable relationship. The

\begin{tabular}{|c|c|}
\hline Variable & Coefficient \\
\hline$e c t_{t-1}$ & $-0.058378^{*}$ \\
\hline$e c t_{t-2}$ & $-0.136997^{*}$ \\
\hline$\Delta \operatorname{exports}_{t-1}$ & $-0.770885^{*}$ \\
\hline$\Delta \operatorname{exports}_{t-2}$ & -0.064200 \\
\hline$\Delta$ imports $_{t-1}$ & 0.101808 \\
\hline imports $_{t-2}$ & -0.118906 \\
\hline inflation $_{t-1}$ & -0.717528 \\
\hline$\Delta$ inflation $_{t-2}$ & $-2.461659 *$ \\
\hline$\Delta$ exchange rate $e_{t-1}$ & 0.490593 \\
\hline$\Delta$ exchange rate $e_{t-2}$ & -0.402662 \\
\hline sinterest rate $_{t-1}$ & -1.287147 \\
\hline interest rate $_{t-2}$ & 1.612054 \\
\hline
\end{tabular}
significance level used was $5 \%$.

Table 7. The VECM Estimation Results for Export That Show the Short-Term Variable Relationship
Based on Table 7, it was found that in the short-term, there were two significant variables to export at the $5 \%$ significance level. The significant variable was the export in the first lag which negatively affected the export at the 5\% significance level. It can be explained that an increase of one percent in export will decrease the export itself by 0.770885 percent.

The second variable was inflation in the second lag which negatively affected the export at the $5 \%$ significance level. It can be explained that an increase of one percent in inflation will decrease the export by 2.461659 . In export, there was an adjustment mechanism from the shortterm to the long-term which was indicated by the significant and negative cointegration errors.

VECM with import as the target variable is displayed as follows:

$$
\begin{aligned}
\text { import }_{t}= & -0.064658 \text { ect }_{t-1}-0.153353 \text { ect }_{t-2}-0.147856 \Delta \text { export }_{t-1} \\
& +0.302665 \Delta \text { export }_{t-2}-0.537494 \Delta \text { import }_{t-1}-0.526892 \Delta \text { import }_{t-2} \\
& -1.730351 \Delta \text { inflation }_{t-1}-2.893331 \text { inflation }_{t-2} \\
& +0.377239 \Delta \text { excahangerate }_{t-1}-0.411728 \Delta \text { exchangerate }_{t-2} \\
& -0.016583 \Delta \text { interestrate }_{t-1}+1.754202 \Delta \text { interestrate }_{t-2}
\end{aligned}
$$

Table 8 is the VECM estimation result of the import which shows the short-term variable relationship with a significance level of $5 \%$. 
Desimal, 3 (3), 2020 - 255

Nina Valentika*, Vivi Iswanti Nursyirwan, Ilmadi

Table 8. The VECM Estimation Result of Import That Show the Short-Term Variable Relationship

\begin{tabular}{|c|c|}
\hline Variable & Coefficient \\
\hline$e c t_{t-1}$ & $-0.064658^{*}$ \\
\hline$e c t_{t-2}$ & $-0.153353^{*}$ \\
\hline$\Delta \operatorname{exports}_{t-1}$ & -0.147856 \\
\hline$\Delta$ exports $_{t-2}$ & 0.302665 \\
\hline$\Delta$ imports $_{t-1}$ & $-0.537494^{*}$ \\
\hline$\Delta$ import $_{t-2}$ & $-0.526892^{*}$ \\
\hline inflation $_{t-1}$ & -1.730351 \\
\hline$\Delta$ inflation $_{t-2}$ & -2.893331 \\
\hline$\Delta$ exchange rate $e_{t-1}$ & 0.377239 \\
\hline$\Delta$ exchange rate $t_{t-2}$ & -0.411728 \\
\hline$\Delta_{\text {interest rate }}$ t-1 & -0.016583 \\
\hline$\Delta$ interest rate $e_{t-2}$ & 1.754202 \\
\hline
\end{tabular}

Based on Table 8, it was found that in the short term, there were two significant to import variables at the $5 \%$ significance level. The variable was the import in the first lag which negatively affected the import. It can be explained that an increase of one percent in imports will reduce the import itself by 0.537494 percent.

the import. It can be explained that an increase of one percent in imports will decrease the import 0.526892 percent. In import, there was an adjustment mechanism from the short-term to the long-term indicated by both significant and negative cointegration errors.

VECM with the inflation as the target

The second variable is the import in the second lag which negatively affected

$$
\begin{aligned}
\text { inflation }_{t}= & 0.000563 \text { ect }_{t-1}-0.000415 \text { ect }_{t-2}+0.001875 \Delta \text { export }_{t-1} \\
& +0.000128 \Delta \text { export }_{t-2}-0.000400 \text { imports }_{t-1}-0.003868 \text { imports }_{t-2} \\
& +0.409537 \Delta \text { inflation }_{t-1}-0.165632 \Delta \text { inflation }_{t-2} \\
& +0.056153 \Delta \text { exchange rate }_{t-1}+0.056469 \Delta \text { exchange rate }_{t-2} \\
& +0.431314 \Delta \text { interest rate }_{t-1}-0.179088 \Delta \text { interest rate }_{t-2}
\end{aligned}
$$

Table 9 is the VECM estimation result of inflation which shows the short-

\begin{tabular}{|c|c|}
\hline Variable & Coefficient \\
\hline$e c t_{t-1}$ & 0.000563 \\
\hline$e c t_{t-2}$ & -0.000415 \\
\hline$\Delta \operatorname{exports}_{t-1}$ & 0.001875 \\
\hline$\Delta \operatorname{exports}_{t-2}$ & 0.000128 \\
\hline $\operatorname{simports}_{t-1}$ & -0.000400 \\
\hline $\operatorname{simports}_{t-2}$ & -0.003868 \\
\hline inflation $_{t-1}$ & $0.409537^{*}$ \\
\hline inflation $_{t-2}$ & -0.165632 \\
\hline$\Delta$ exchange rate $e_{t-1}$ & 0.056153 \\
\hline$\Delta$ exchange rate $e_{t-2}$ & $0.056469 *$ \\
\hline$\Delta_{\text {interest rate }}$ & 0.431314 \\
\hline$\Delta_{\text {interest rate }}{ }_{t-2}$ & -0.179088 \\
\hline
\end{tabular}

term variable relationship with a significance level of $5 \%$.

Table 9. The VECM Estimation Results of Inflation That Show the Short-Term Variable Relationship 
Based on Table 9, two variables were significant to inflation at the $5 \%$ significance level. This first variable was the inflation in the first lag which positively affected the inflation. It can be explained that an increase of one percent in inflation will increase the inflation itself by 0.409537 percent.
The second variable was the exchange rate at the second lag which positively affected the inflation. It can be explained that an increase of one percent in the exchange rate will increase the inflation by 0.056469 percent.

VECM with the exchange rate as the target variable is as follows:

$\Delta$ exchange rate t $_{t}$

$$
\begin{aligned}
& =0.006171 \text { ect }_{t-1}+0.016950 \text { ect }_{t-2}-0.018421 \Delta \text { export }_{t-1} \\
& -0.000543 \Delta \text { export }_{t-2}-0.010623 \Delta \text { import }_{t-1}-0.001996 \Delta \text { import }_{t-2} \\
& +0.264227 \Delta \text { inflation }_{t-1}+0.099278 \Delta \text { inflation }_{t-2} \\
& +0.213066 \Delta \text { exchange rate }_{t-1}-0.233988 \Delta \text { exchange rate }_{t-2} \\
& +1.535983 \Delta \text { interest rate }_{t-1}+0.713371 \Delta \text { interest rate }_{t-2}
\end{aligned}
$$

(4)

Table 10 shows the VECM estimation result of the exchange rate which shows the short-term variable relationship at a

\begin{tabular}{|c|c|}
\hline Variable & Coefficient \\
\hline$e c t_{t-1}$ & $0.006171^{*}$ \\
\hline$e c t_{t-2}$ & $0.016950^{*}$ \\
\hline$\Delta \operatorname{exports}_{t-1}$ & -0.018421 \\
\hline$\Delta \operatorname{exports}_{t-2}$ & -0.000543 \\
\hline$\Delta$ imports $_{t-1}$ & -0.010623 \\
\hline simports $_{-0.001996}$ & $t-2$ \\
\hline inflation $_{0.264227}$ & $t-1$ \\
\hline sinflation $_{0.099278}$ & $t-2$ \\
\hline sexchangerate $_{0.213066}$ & $t-1^{*}$ \\
\hline$\Delta$ exchangerate $e_{-0.233988}$ & $t-2^{*}$ \\
\hline$\Delta$ interest rate $e_{1.535983}$ & $t-1$ \\
\hline sinterest rate $_{0.713371 t}$ & 2 \\
\hline
\end{tabular}
significance level of $5 \%$.

Table 10. The VECM Estimation Results of the Exchange Rate That Show the

Short-Term Variable Relationship

Based on Table 10, it is found that in the short-term, there were two significant variables to the exchange rate at the $5 \%$ significance level. The first variable was the exchange rate in the first lag which positively affected the exchange rate. It can be explained that an increase of one percent in the first lag of the exchange rate will increase the exchange rate itself by 0.213066 percent.

The second variable was the exchange rate in the second lag which positively affected the exchange rate. It can be explained that an increase of one percent in the exchange rate in the second lag, the exchange rate will decrease by 0.233988 percent. In inflation, there was an adjustment mechanism from the shortterm to the long-term indicated by two significant cointegration errors.

VECM with the interest rate as the target variable is as follows:

$$
\begin{aligned}
& \Delta \text { interest rate }_{t} \\
& =0.000167 \text { ect }_{t-1}+0.000553 \text { ect }_{t-2}+0.003129 \Delta \text { export }_{t-1} \\
& +0.000340 \Delta \text { export }_{t-2}+0.002148 \Delta \text { import }_{t-1}+0.001674 \Delta \text { import }_{t-2} \\
& +0.045677 \Delta \text { inflation }_{t-1}-0.007648 \Delta \text { inflation }_{t-2} \\
& +0.002259 \Delta \text { exchangerate }_{t-1}-0.001566 \Delta \text { exchange rate }_{t-2} \\
& +0.359769 \text { interest }_{\text {inat }}{ }_{t-1}+0.157656 \text { interest rate } \text { in }_{t-2}
\end{aligned}
$$


Desimal, 3 (3), 2020 - 257

Nina Valentika*, Vivi Iswanti Nursyirwan, Ilmadi

Table 11 shows the VECM estimation short-term variable relationship at a result of the interest rate which shows the significance level of $5 \%$.

Table 11. The VECM Estimation Result of the Interest Rate Which Shows the Short-Term Variable Relationship

\begin{tabular}{|c|c|}
\hline Variable & Coefficient \\
\hline$e c t_{t-1}$ & 0.000167 \\
\hline$e c t_{t-2}$ & 0.000553 \\
\hline$\Delta \operatorname{exports}_{t-1}$ & 0.003129 \\
\hline$\Delta \operatorname{exports}_{t-2}$ & 0.000340 \\
\hline$\Delta i m p o r t s_{t-1}$ & 0.002148 \\
\hline imports $_{t-2}$ & 0.001674 \\
\hline inflation $_{t-1}$ & 0.045677 \\
\hline sinflation $_{t-2}$ & -0.007648 \\
\hline$\Delta$ exchange rate $e_{t-1}$ & 0.002259 \\
\hline$\Delta$ exchange rate $e_{t-2}$ & -0.001566 \\
\hline$\Delta_{\text {interest rate }}$ t-1 & $0.359769^{*}$ \\
\hline$\Delta_{\text {interest }}$ rate $_{t-2}$ & 0.157656 \\
\hline
\end{tabular}

Based on Table 11, it was found that in the short term, there was one significant variable to the interest rate at a significance level of $5 \%$. This variable was the interest rate in the first lag which positively affected the interest rate. It can be explained that an increase of one percent in the first lag interest rate will increase the interest rate itself by 0.359769 percent.

The cointegration equation (longrun model) for $e c t_{t-1}$ is as follows:

$$
\begin{gathered}
\text { ect }_{t-1}=1.0000 \text { exports }_{t-1}-220.9148 \text { inflation }_{t-1}-4.642013 \text { exchange rate }_{t-1} \\
+192.0311 \text { interest rate }_{t-1}+17.83737
\end{gathered}
$$

The results of the VECM estimation that shows the long-term relationship for ect $t_{t-1}$ can be seen in Table 12.

Table 12. The VECM Estimation Results That Show the Long-Term Relationship for

\begin{tabular}{|c|c|c|}
\hline Variable & Coefficient & t-statistics \\
\hline exports $_{-1}$ & 1.0000 & \\
\hline inflation $_{t-1}$ & $-220.9148^{*}$ & -4.85488 \\
\hline exchange rate $_{t}$. & -4.642013 & -1.53300 \\
\hline interest rate $_{t-1}$ & $192.0311^{*}$ & 2.64564 \\
\hline Constant & 17.83737 & 0.61084 \\
\hline
\end{tabular}

$$
\text { ect } t_{t-1}
$$

Based on Table 12, it was found that there were two variables affected the export in the long-term. The inflation with a coefficient of $-220,9148$ indicated that an increase of one percent of the inflation will reduce the export by 220,9148 percent. The interest rate with a coefficient of 192.0311 indicated that an increase of the interest rate of one percent will increase the export by 192.0311 percent.

The cointegration equation (longrun model) for $e c t_{t-2}$ is as follows: 
Desimal, 3 (3), 2020 - 258

Nina Valentika*, Vivi Iswanti Nursyirwan, Ilmadi

$$
\begin{gathered}
\text { ect }_{t-2}= \\
\text { 1.0000imports } \\
-63.27930 \text { interest rate }_{t-1}-45.74021
\end{gathered}
$$

The results of VECM estimation that show a long-term relationship for $e c t_{t-2}$ can be seen in Table 13.

Table 13. The VECM Estimation Results That Show the Long-Run for $e t_{t-2}$

\begin{tabular}{ccc}
\hline Variable & Coefficient & t-statistics \\
exports $_{-1}$ & 1.0000 & \\
inflation $_{-1}$ & $86.87339^{*}$ & 4.61750 \\
exchange rates $_{t-:}$ & 2.412033 & 1.92657 \\
interest rate $_{-1}$ & $-63.27930^{*}$ & -2.10857 \\
Constant & $-45.74021^{*}$ & -3.78842 \\
\hline *at 5\% significance level. &
\end{tabular}

Based on Table 13, it was found that two variables affected the import in the long-term. The inflation with a coefficient of 86.87339 indicated that an increase of inflation by one percent will increase the import by 86.87339 percent. The interest rate with a coefficient of $-63,27930$ indicated that an increase of the interest rate by one percent will reduce the import by 63,27930 percent.

The forecasting model to forecast the export can be seen in Table 14.

Table 14. The Forecasting Model to Forecast the Export

\begin{tabular}{|llll}
\hline \multicolumn{1}{c}{ Months } & $\begin{array}{c}\text { The Forecasting } \\
\text { Results }\end{array}$ & \multicolumn{1}{c}{$\begin{array}{c}\text { Analytical } \\
\text { Results }\end{array}$} & \multicolumn{1}{c}{ Relative Error } \\
\hline January 2020 & 23.43778 & 23.33569 & $0: 44$ \\
February 2020 & $23.43779 \%$ & 23.36666373 & $00: 30$ \\
in March 2020 & 23.43779 & $23.36716144 \%$ & $0: 30$ \\
April 2020 & 23.4378 & $23.22167262 \%$ & $0.93 \%$ \\
May 2020 & 23.4378 & 23.07785497 & $1.56 \%$ \\
June 2020 & 23.43781 & 23.2108107 & $0.98 \%$ \\
\hline
\end{tabular}

Based on Table 14, the forecasting model showed that each month, the relative error was less than $5 \%$. Thus, this research model is good at forecasting the export. The forecasting model for forecasting the exchange rates can be seen in Table 15.

Table 15. The Forecasting Model to Forecast the Exchange Rates

\begin{tabular}{llll}
\hline Months & $\begin{array}{l}\text { The } \\
\text { Forecasting } \\
\text { Results }\end{array}$ & $\begin{array}{l}\text { Analytica } \\
\text { I Results }\end{array}$ & $\begin{array}{l}\text { Relative } \\
\text { Error }\end{array}$ \\
\hline January 2020 & 9.151702 & 9.527501 & $3.94 \%$ \\
February 2020 & 9.151699 & 9.530694 & $3.98 \%$ \\
March 2020 & 9.151697 & 9.628693 & $4.95 \%$ \\
April 2020 & 9.151695 & 9.672024 & $5.38 \%$ \\
May 2020 & 9.151693 & 9.609532 & $4.76 \%$ \\
June 2020 & 9.151691 & 9.560712 & $4.28 \%$ \\
\hline
\end{tabular}


Based on Table 15, the forecasting results showed that not every month the relative error was less than $5 \%$. Thus, this research model is inappropriate to forecast exchange rates. The forecasting model to forecast the interest rates can be seen in Table 16.

Table 16. The Forecasting Model to Forecast the Interest Rates

\begin{tabular}{llll}
\hline Months & $\begin{array}{l}\text { The Forecasting } \\
\text { Results }\end{array}$ & $\begin{array}{l}\text { Analytica } \\
\text { l Results }\end{array}$ & $\begin{array}{l}\text { Relative } \\
\text { Error }\end{array}$ \\
January 2020 & 0.068544 & 0.05 & $37.09 \%$ \\
February 2020 & 0.068544 & 0.0475 & $44.30 \%$ \\
March 2020 & 0.068544 & 0.045 & $52.32 \%$ \\
April 2020 & 0.068543 & 0.045 & $52.32 \%$ \\
May 2020 & 0.068543 & 0.045 & $52.32 \%$ \\
June 2020 & 0.068543 & 0.0425 & $61.28 \%$ \\
\hline
\end{tabular}

Based on Table 16, the forecasting results showed that each month, the relative error was greater than $5 \%$. Thus, this research model is inappropriate to forecast interest rates. The forecasting model to forecast the import can be seen in Table 17.

Table 17. The Forecasting Model to Forecast the Import

\begin{tabular}{llll}
\hline \multicolumn{1}{c}{ Months } & $\begin{array}{l}\text { The Forecasting } \\
\text { Results }\end{array}$ & $\begin{array}{l}\text { Analytical } \\
\text { Results }\end{array}$ & $\begin{array}{l}\text { Relative } \\
\text { Error }\end{array}$ \\
\hline January 2020 & 23.30191 & 23.38133 & $0.34 \%$ \\
February 2020 & 23.30192 & 23.169787 & $0.57 \%$ \\
March 2020 & 23.30193 & 23.314947 & $0.06 \%$ \\
April 2020 & 23.30193 & 23.251807 & $0.22 \%$ \\
May 2020 & 23.30194 & 22.856497 & $1.95 \%$ \\
June 2020 & 23.30194 & 23.099501 & $0.88 \%$ \\
\hline
\end{tabular}

Based on Table 17, the forecasting results showed that each month, the relative error was less than $5 \%$. Thus, this research model is appropriate to forecast the import. The forecasting model to forecast inflation can be seen in Table 18.

Table 18. The Forecasting Model to Forecast the Inflation

\begin{tabular}{llll}
\hline Months & $\begin{array}{l}\text { The Forecasting } \\
\text { Results }\end{array}$ & $\begin{array}{l}\text { Analytical } \\
\text { Results }\end{array}$ & $\begin{array}{l}\text { Relative } \\
\text { Error }\end{array}$ \\
January 2020 & 0.054115 & 0.0268 & $101.92 \%$ \\
February 2020 & 0.054115 & 0.0298 & $81.59 \%$ \\
March 2020 & 0.054115 & 0.0296 & $82.82 \%$ \\
April 2020 & 0.054115 & 0.0267 & $102.68 \%$ \\
May 2020 & 0.054115 & 0.0219 & $147.10 \%$ \\
June 2020 & 0.054116 & 0.0196 & $176.10 \%$ \\
\hline
\end{tabular}

Based on Table 18, the forecasting results showed that each month, the relative error was more than $5 \%$. Thus, this research model is inappropriate to forecast inflation. Granger's Causality test can be seen in Table 19. 
Table 19. The Granger Causality Test

\begin{tabular}{|c|c|c|}
\hline $\mathrm{H}_{0} * *$ & F-Statistic & Prob. \\
\hline EXPORT does not cause EXCHANGE RATE & 0.4130 & 0.89079 \\
\hline EXCHANGE RATE does not cause EXPORT & 0.2028 & 1.61638 \\
\hline INTEREST RATE does not cause EXCHANGE RATE & 0.0553 & 2.96424 \\
\hline EXCHANGE RATE does not cause INTEREST RATE & 0.9068 & 0.09788 \\
\hline IMPORT does not cause EXCHANGE RATE & 0.4384 & 0.83026 \\
\hline EXCHANGE RATE does not cause IMPORT & 0.5429 & 0.61384 \\
\hline INFLATION does not cause EXCHANGE RATE & 0.7953 & 0.22944 \\
\hline EXCHANGE RATE does not cause INFLATION* & 0.0180 & 4.15210 \\
\hline INTEREST RATE does not cause EXPORT & 0.1917 & 1.67442 \\
\hline EXPORT does not cause INTEREST RATE * & 0.0149 & 4.35589 \\
\hline IMPORT does not cause EXPORT & 0.0899 & 2.45695 \\
\hline EXPORT does not cause IMPORT * & 0.0057 & 5.38927 \\
\hline INFLATION does not Cause EXPORT * & 0.0313 & 3.56493 \\
\hline EXPORT does not cause INFLATION & 0.8830 & 0.12456 \\
\hline IMPORT does not cause INTEREST RATE * & 0.0054 & 5.45778 \\
\hline INTEREST RATE does not cause IMPORT & 0.7862 & 0.24106 \\
\hline INFLATION does not cause INTEREST RATE & 2.35608 & 0.0991 \\
\hline INTEREST RATE does not cause INFLATION & 0.35632 & 0.7010 \\
\hline INFLATION does not cause IMPORT & 2.28149 & 0.1064 \\
\hline IMPORT does not cause INFLATION & 0.08432 & 0.9192 \\
\hline
\end{tabular}

Based on Table 19, the exchange rates significantly influence inflation. This result is relevant to Madesha, et al. (2013) that inflation greatly influences the exchange rates' fluctuations (Madesha et al., 2013). The export significantly influences interest rates. The export significantly influences the import. inflation significantly influences export. The import significantly influences the interest rate

\section{CONCLUSIONS AND SUGGESTIONS}

It can be concluded that the intervariables model in this research was the VECM model with lag 2. It used the deterministic trend with the assumption of none intercept no trend and there was two cointegration. There was an adjustment mechanism in import and export in the short-term and long-term. The model was appropriate to forecast export and import. Based on Granger's Causality test, there was a one-way relationship between the exchange rates and inflation, between export and interest rates, between export and import, between inflation and export, and between import and interest rates at a significance level of 5\%. Further research is expected to add other macroeconomic factors.

\section{ACKNOWLEDGEMENT}

This research is funded by the Kementerian Riset dan Teknologi/Badan Riset dan Inovasi Nasional, No. 0113/D5/KP/LPPM/IV/2020.

\section{REFERENCES}

Bank Indonesia. (2020). Data inflasi. Bank Indonesia.

Besimi, F., Pugh, G. T., \& Adnett, N. J. (2006). The monetary transmission mechanism in Macedonia: implications for monetary policy. Centre for Research on Emerging Economies Working Paper, 02-2006.

Catalbas, N. (2016). The relationship among nominal exchange rate, import and export in Turkey for the period 1988: 1 to 2015: 3 . 
International Research Journal of Applied Finance, 7(4), 11-25.

Chou, W. L. (2000). Exchange rate variability and China's exports. Journal of Comparative Economics, 28(1), 61-79.

Enders, W. (2014). Applied econometric time series (4th ed.). Wiley.

Firdaus, M. (2011). Aplikasi ekonometrika untuk data panel dan time series. IPB Press.

Granger, C. W., Newbold, P., \& Econom, J. (1974). Spurious regressions in econometrics. Baltagi, Badi H. A Companion of Theoretical Econometrics, 557-561.

Kewal, S. S. (2012). Pengaruh inflasi, suku bunga, kurs, dan pertumbuhan PDB terhadap indeks harga saham gabungan. Jurnal Economia, 8(1), 5364.

Lütkepohl, H. (2005). New introduction to multiple time series analysis. Springer Science \& Business Media.

Madesha, W., Chidoko, C., \& Zivanomoyo, J. (2013). Empirical test of the relationship between exchange rate and inflation in Zimbabwe. Journal of Economics and Sustainable Development, 4(1), 52-58.

Mankiw, N. G. (2008). Principles of macroeconomics (5th ed.). Cengage Learning.

Mishkin, F. S. (2008). Ekonomi uang, perbankan, dan pasar keuangan. Salemba Empat.

Muhammad Hendartyo. (2020). Rupiah Melemah Sejak Akhir 2019, BI Optimalkan Operasi Moneter. Tempo.Co.

Muzakky, A., Suhadak, \& Topowijono. (2015). Pengaruh inflasi, tingkat suku bunga SBI, pendapatan per kapita, dan ekspor terhadap nilai tukar rupiah dan pertumbuhan ekonomi studi pada Bank Indonesia periode tahun 2002-2013. Jurnal Administrasi Bisnis, 23(1), 1-9.

Pratikto, R. (2012). Dynamics of Indonesia's international trade a VAR approach. Procedia Economics and Finance, 4, 149-159.

Rinaldi, A. (2019). Model persamaan struktural untuk menganalisis indikator kesejahteraan rumah tangga. Desimal: Jurnal Matematika, 2(3), 281-288.

Silitonga, R. B., Ishak, Z., \& Mukhlis. (2017). Pengaruh ekspor, impor, dan inflasi terhadap nilai tukar rupiah di Indonesia. Jurnal Ekonomi Pembangunan, 15(1), 53-59.

Sukirno, S. (2002). Teori mikro ekonomi. PT Raja Grafindo Perkasa.

Sukirno, S. (2013). Makroekonomi teori pengantar. PT Raja Grafindo Perkasa.

Verbeek, M. (2008). A guide to modern econometrics. Wiley. 
Desimal, 3 (3), 2020 - 262

Nina Valentika*, Vivi Iswanti Nursyirwan, Ilmadi 